\title{
LOW-COST BASE ISOLATION SYSTEMS FOR UNREINFORCED MASONRY BUILDINGS IN DEVELOPING COUNTRIES
}

\author{
Nagavinothini Ravichandran ${ }^{1}$, Daniele Losanno ${ }^{1}$, and Fulvio Parisi ${ }^{1,2}$ \\ ${ }^{1}$ Department of Structures for Engineering and Architecture, University of Naples Federico II, Via \\ Claudio 21, 80125, Napoli, Italy \\ e-mail: \{nagavinothini.ravichandran, daniele.losanno, fulvio.parisi\}@unina.it \\ ${ }^{2}$ Institute for Complex Systems, National Research Council of Italy, Via dei Taurini 19, 00185 Rome, \\ Italy
}

\begin{abstract}
Unreinforced masonry (URM) buildings are one of the most common constructions in developing countries and are usually constructed based on traditional knowledge without engineering intervention. Due to poor seismic performance of URM buildings, the development of seismic protection systems can play a key role in the mitigation of losses in future earthquakes. Despite the availability of different interventions for seismic strengthening of URM buildings, the quest for a cost-effective technique still exits. On the basis of recent outcomes by these authors, this study presents the design of low-cost base isolation systems for a class of URM buildings deemed representative of the building stock of developing countries. The proposed base-isolation system is made by recycled-rubber fibre-reinforced elastomeric isolators (RR-FREIS). Building classes were defined by properly selecting those parameters which are expected to mostly affect the seismic behaviour of the building such as number of storeys, masonry type and in-plan irregularity. Three-dimensional numerical models of URM buildings were developed in SAP2000 using nonlinear layered shell elements and bilinear models for RR-FREIs. Nonlinear time history analyses were carried out for a set of ground motion records to investigate the performance of both fixed-base (FB) and base-isolated (BI) configurations of URM buildings. The comparison of results shows a significant reduction of inter-storey drift ratios for BI configuration, thus demonstrating the effectiveness of RRFREIs.
\end{abstract}

Keywords: Unreinforced masonry buildings, base isolation system, recycled rubber, fiber reinforced elastomeric isolators, finite element analysis. 


\section{INTRODUCTION}

Unreinforced masonry (URM) buildings are usually constructed using locally available bricks, based on traditional knowledge without engineering intervention. Such non-engineered constructions (NEC) are highly susceptible to damage when subjected to lateral loads like seismic motion. This is mainly due to the lack of seismic design, low strength construction materials and poor structural detailing [1]. The common URM buildings found in developing nations of the world are constructed using masonry walls with roofs made up of reinforced concrete. Such type of buildings tends to develop deep cracks and undergo significant damage even under moderate earthquakes [2]. The collapse of such non-engineered and semiengineered buildings during seismic events had resulted in huge losses especially in developing nations like India, Nepal, Philippines, Pakistan, Mexico, and Indonesia. Notable events include the 2006 Yogyakarta earthquake and 2005 Kashmir earthquake in India and Pakistan, respectively [3].

Considering the economic impact, the complete replacement of NECs with earthquakeresistant buildings is unfeasible. Hence, there is a need for a sustainable control strategy with reduced cost. One of the promising solutions is the base isolation technology in which the seismic response of the superstructure is reduced by introducing isolation bearings between the superstructure and the foundation of the building $[4,5,6]$. However, the cost of the base isolation system being high, the application is usually limited to important structures such as hospitals and historic buildings. The continuous development in this field had led to the development of novel configurations of elastomeric bearings for base isolation. Among these, fibre-reinforced elastomeric isolators (FREIs) have been developed in the recent years as an alternative to conventional laminated rubber bearings $[7,8]$. The replacement of internal shims with flexible reinforcement makes FREIs less heavy and easier to install in comparison with conventional isolators.

In order to further reduce the cost of FREIs, significant research effort is being dedicated currently to developing a novel elastomeric bearing using recycled rubber. The extremely low cost of recycled-rubber fibre-reinforced elastomeric isolators (RR-FREIs) would make them highly suitable for application in developing nations $[9,10,11,12]$. However, research on the suitability and effectiveness of the novel RR-FREIs for base isolation of URM buildings is scarce in the literature [13]. A recent study by Losanno et al. investigated the effectiveness of RR-FREIs for a box-type URM building in developing nations [14]. The study assessed the response of fixed-base (FB) and base-isolated (BI) building models developed based on macro-modelling approach using SAP2000 [15]. The use of such simplified macro-modelling approach for nonlinear analysis of base-isolated structures can be widely seen in the literature $[16,17]$. Developing a suitable modelling approach with acceptable accuracy is necessary to capture the exact response of the masonry structures [14,18,19,20].

In this context, the present study aims at investigating the effect of low-cost base isolation system on typical URM buildings from the stock of developing nations. Three building types were chosen in order to address the effect of plan variability, wall density and number of storeys on effectiveness of base isolation under a set of earthquake records. Nonlinear time history analyses of the FB and BI-URM buildings were carried out using a simplified threedimensional numerical model developed in SAP2000.

\section{SELECTION OF CASE STUDIES}

Three different masonry buildings representing URM buildings in developing nations are considered for the aim of the study. The first building prototype (URM1) is a single-story building reported by Shahzada et al. (2012) with plan dimensions $4.115 \mathrm{~m} \times 3.505 \mathrm{~m}$, built 
with 0.228-m-thick walls as shown in Figure 1a. The experimental and numerical analysis results of URM1 are available in the literature [14,21,22]. The second building prototype (URM2) is selected based on a detailed investigation on the URM building stock in developing nations and the building plan with dimensions $8.0 \mathrm{~m} \times 6.0 \mathrm{~m}$ is shown in Figure $1 \mathrm{~b}$. The building plan is framed by also considering the Indian Standards for earthquake design [23]. The third building prototype (URM3) considered in the study is a two-storey building with the same building plan of URM2.

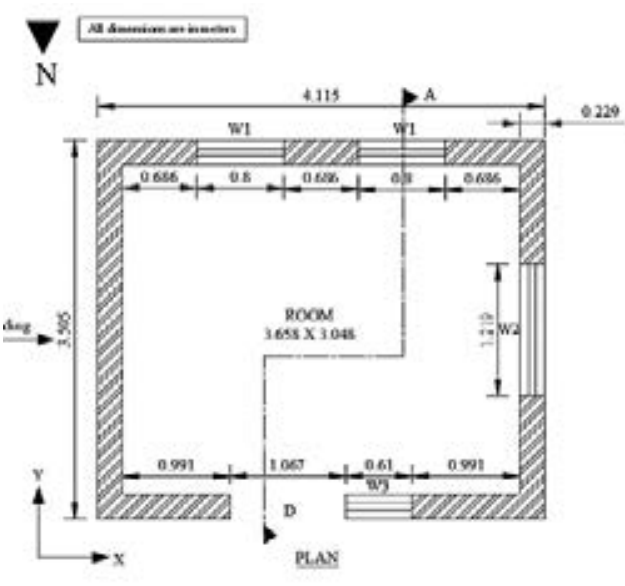

(a)

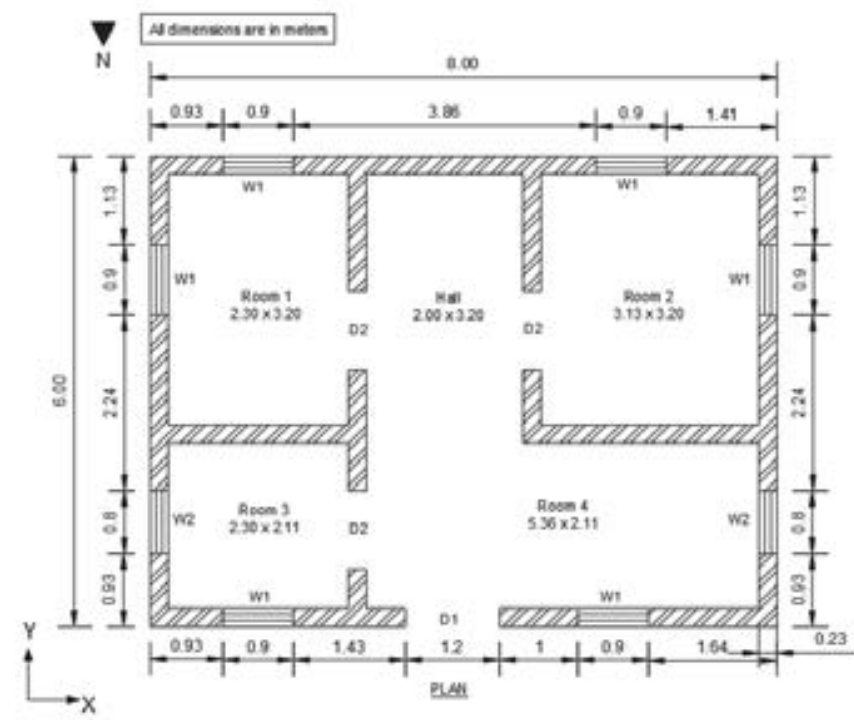

(b)

Figure 1: Plan view of URM buildings: (a) URM1; (b) URM2 and URM3.

The wall thickness is constant in plan and elevation, and equal to $0.228 \mathrm{~m}$; the roof of the URM buildings was considered to be made up of $0.152 \mathrm{~m}$ reinforced concrete slab. Further, the buildings were also provided with a $0.152 \mathrm{~m}$ thick $\mathrm{RC}$ lintel above the openings to improve the building resistance to gravity loads. The inter-storey height of the structures was taken equal to $3.3 \mathrm{~m}$. Mohr-Coulomb failure criterion with associated flow rule was used for simulating the inelastic shear behaviour and failure of the masonry. The RC elements were assumed as linear elastic and a rigid diaphragm constraint was assigned to the roof level of the buildings.

In order to consider the variability of mechanical properties, the material properties of the masonry structures considered in the present study were selected from previous studies on URM buildings located in developing nations such as India, Nepal, Pakistan and Iran $[21,24,25,26,27]$. The statistical distributions, mean value and coefficient of variation $(\mathrm{CoV})$ of the main material properties are listed in Table 1.

\begin{tabular}{llll}
\hline Material properties & Distribution & Mean & CoV \\
\hline Mass density $\left[\mathrm{kg} / \mathrm{m}^{3}\right]$ & Lognormal & 1707.5 & 0.13 \\
Compressive strength $[\mathrm{MPa}]$ & & 4.2 & 0.43 \\
Tensile strength $[\mathrm{MPa}]$ & & 0.16 & 0.56 \\
Shear strength $[\mathrm{MPa}]$ & & 0.24 & 0.66 \\
Young's modulus $[\mathrm{MPa}]$ & & 1302 & 0.68 \\
\hline
\end{tabular}

Table 1: Material properties of URM buildings. 


\section{DESIGN OF BASE ISOLATION SYSTEM}

Detailed research on RR-FREIs has been carried out in the recent years both numerically and experimentally. The RR-FREI sample and its experimental shear behaviour obtained from Losanno et al. (2020) is shown in Figure 2 [12]. These bearings are made up of rubber grains from used tires and industrial leftovers that are crumbled and glued together. The devices are installed in unbounded configuration in order to achieve an easier installation and significantly releasing internal stress within the isolator. The cost of this innovative RR-FREIs has been estimated in the order of $10 \%$ of the cost of conventional laminated rubber bearings.

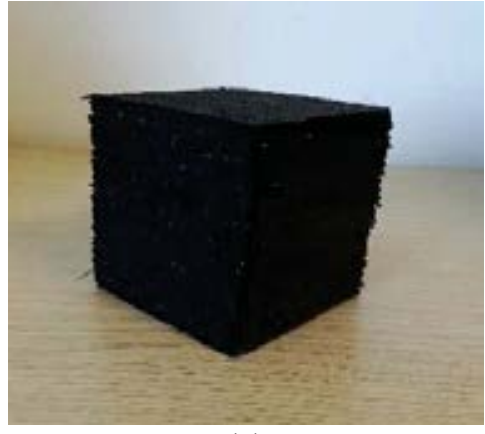

(a)

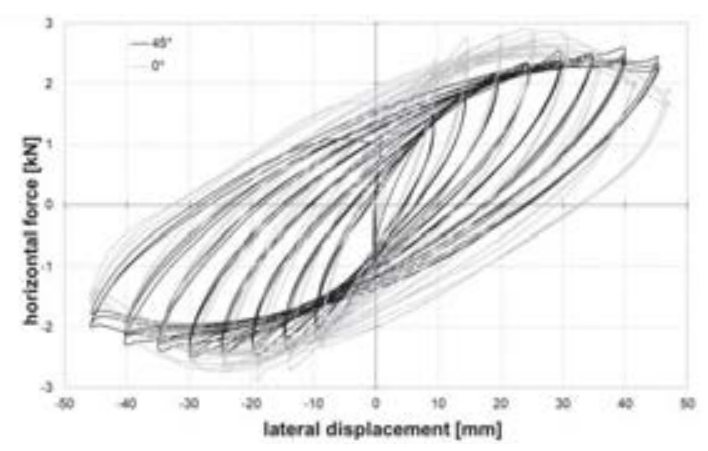

(b)

Figure 2: RR-FREI prototype: (a) picture; (b) experimental shear behaviour [12].

The weight of the building plays a major role in the design of rubber-based isolation systems. Considering the low weight of single-story URM buildings, only a smaller number of bearings would be required to achieve a conventional target period in the range of 2.00 to 2.50 s. But the requirement of a deep beam spanning over the whole length of the masonry walls poses a major challenge. In order to maintain the overall lateral stiffness of the system, a suitable trade-off needs to be identified while designing the base isolation systems with a limited number of bearings trying to avoid a deep base-beam. In the present study, the reinforced concrete base beam was designed in accordance with Indian code provisions confirming minimum concrete strength and internal reinforcement for URM buildings. The width of the base bond beam is maintained same as that of the wall thickness. Dead load analysis of finite element model was carried out with varying support locations to identify the most suitable position of the least number of isolators while satisfying the requirements in terms of both stress and deformation limits provided by the code. The number of isolators used in the three BIURM buildings considered in the present study is equal to 8 (URM1) and 15 (URM2 and URM3), respectively. The layout of the isolation bearings is shown in Figure 3.

The properties of the square RR-FREIs used in the building prototypes are listed in Table 2 . Square-shaped devices are considered for the possibility of easy cutting RR-FREIs from larger size rubber pads. The width of the bearing is defined according to stability requirements. The target period of BI-URM buildings is obtained as a trade-off between the longer period range for a more significant mitigation of spectral accelerations and the lower period value corresponding to limited displacement demand of the isolation system.

According to previous studies by the authors, the stability limit and damping capacity of RR-FREIs were set equal to $50 \%$ shear strain and $15 \%$ of critical damping, respectively [11]. Shear modulus for URM1 was set equal to $0.70 \mathrm{MPa}$ [14]. A lower value of that modulus, i.e. $0.40 \mathrm{MPa}$, was selected for URM2 and URM3 in order to obtain a more stable geometry of the bearings. A laboratory investigation is being developed in order to reduce the shear modulus to a value which is typical of a softer compound. 


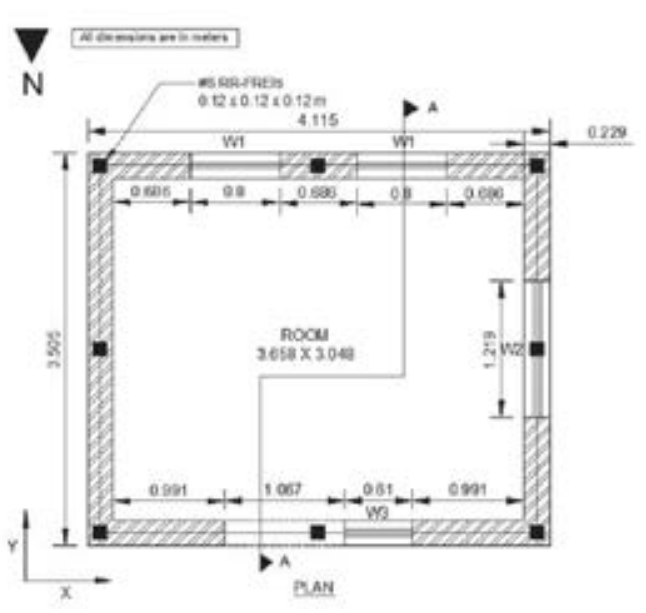

(a)

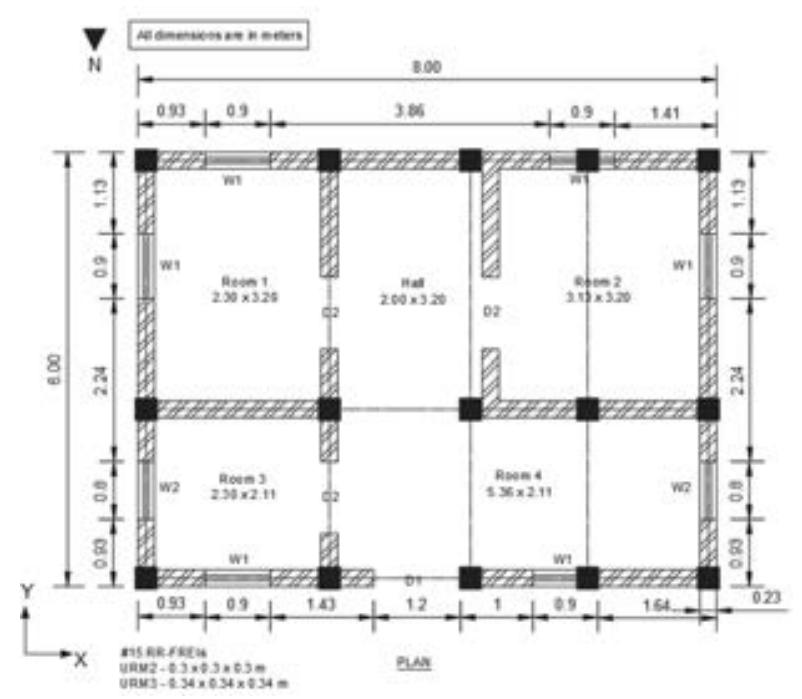

(b)

Figure 3: Location of RR-FREIs in URM buildings: (a) URM1; (b) URM2 and URM3.

\begin{tabular}{lllllll}
\hline $\begin{array}{l}\text { Building } \\
\text { model }\end{array}$ & $\begin{array}{l}\text { FB funda- } \\
\text { mental pe- } \\
\text { riod (s) }\end{array}$ & $\begin{array}{l}\text { Target BI } \\
\text { period }(\mathrm{s})\end{array}$ & $\begin{array}{l}\text { Target dis- } \\
\text { placement } \\
(\mathrm{mm})\end{array}$ & $\begin{array}{l}\text { Equivalent } \\
\text { damping } \\
(\%)\end{array}$ & $\begin{array}{l}\text { Shear } \\
\text { modulus } \\
(\mathrm{MPa})\end{array}$ & $\begin{array}{l}\text { Rubber } \\
\text { height } \\
(\mathrm{mm})\end{array}$ \\
\hline URM1 & 0.12 & 1.30 & 60 & 15 & 0.70 & 120 \\
URM2 & 0.10 & 1.50 & 150 & 15 & 0.40 & 300 \\
URM3 & 0.14 & 1.70 & 170 & 15 & 0.40 & 340 \\
\hline
\end{tabular}

Table 2: Properties of RR-FREIs used in BI-URM buildings.

Due to increasing weight, a higher target period can be achieved with larger URM buildings, i.e. URM2 and URM3 in comparison with URM1. The variability associated with the properties of the isolators is not considered in the present study.

\section{NUMERICAL MODELLING OF URM BUILDINGS}

Masonry being a complex material demands extensive computational effort and experienced users in order to model the exact characteristics of the structure. Further, the inclusion of orthotropic properties of masonry requires additional material properties that are not readily available. Thus, a detailed experimental study on the masonry structure under investigation is necessary to reproduce the realistic behaviour of the masonry through numerical modelling. Hence, simplified macro-modelling techniques are preferred when the aim of the research is mainly focussed on the global behaviour of the structure. In macro-modelling techniques, masonry is modelled as a homogeneous material with equivalent mechanical properties.

The numerical model of the buildings was developed using this simplified macromodelling approach in SAP2000 software package with nonlinear layered shell elements. In this macro-modelling approach, masonry was considered as an isotropic material. The shell layers are defined with different constitutive law in the thickness direction. Two stress-strain curves corresponding to normal and shear stresses were used to represent the nonlinear behaviour of the masonry $[1,16]$. The uniaxial compressive strength of the masonry was defined based on the analytical model developed by Kaushik et al. [28]. The uniaxial tensile strength of the masonry was defined based on the relationship suggested by Akhaveissy and Milani 
[29]. The presented numerical approach had also been proven to be accurate and computationally efficient compared to other micro modelling approaches used in masonry modelling. The comparison of numerical and experimental results of the box-type structure can be seen in Losanno et al. [14]. Furthermore, a detailed research article on the comparison of different macro-modelling approaches for URM buildings highlights the suitability of this method [30]. In case of base-isolated buildings, the $\mathrm{RC}$ base beam is modelled using linear elastic frame elements. The RR-FREIs are modelled using a simplified bilinear model to account for nonlinear behaviour of the bearings. The initial and post-yielding stiffness values were used in order to provide the effective stiffness and equivalent damping ratio obtained with the base isolation system design according to values listed in Table 2. The numerical models of the base-isolated buildings along with their first mode of vibration are shown in Figure 4. The first mode of BI-URM buildings clearly shows the rigid-body motion in the superstructure.

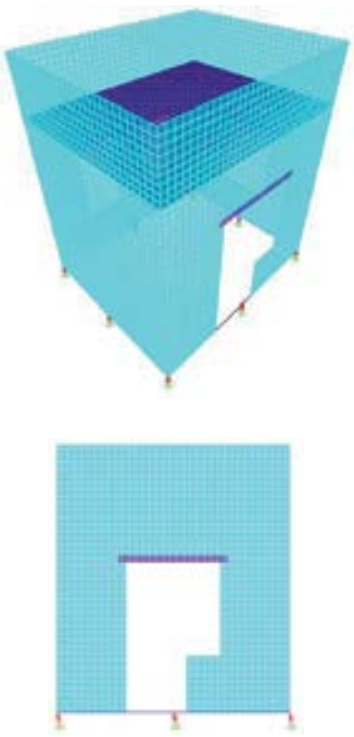

(a)

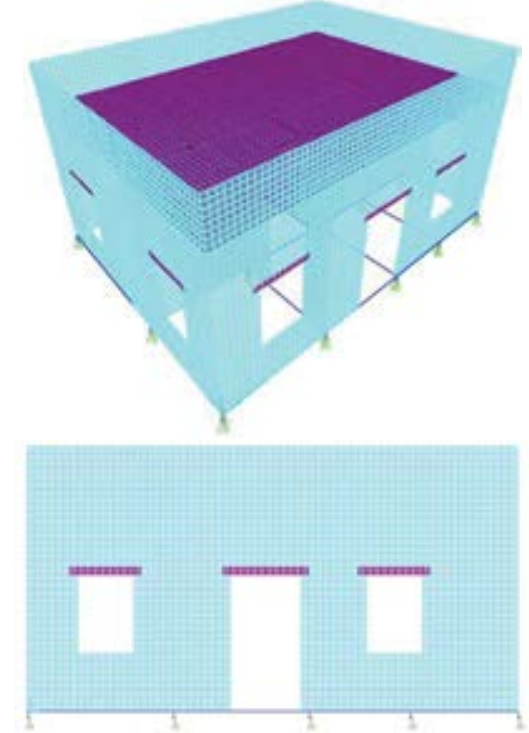

(b)

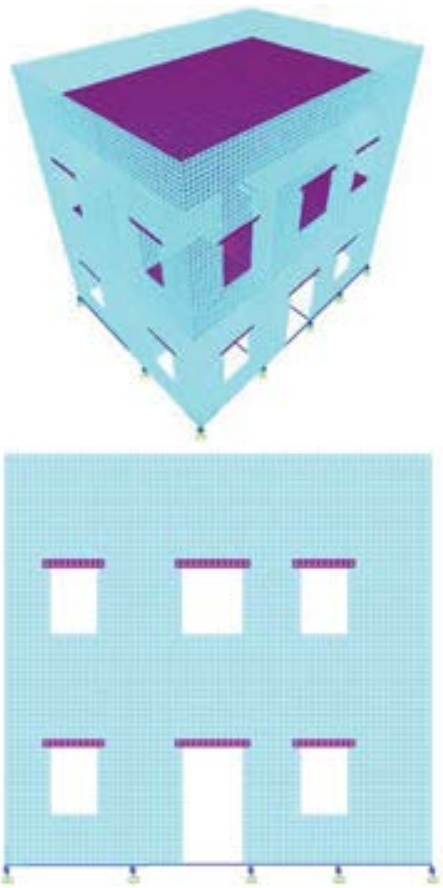

(c)

Figure 4: Numerical model (first mode of vibration) of base-isolated buildings using RR-FREIs: (a) URM1; (b) URM2; (c) URM3.

\section{SEISMIC ANALYSIS OF URM BUILDINGS}

In order to consider the uncertainties associated with earthquake ground motion (i.e. record-to-record variability), the response of the FB- and BI-URM buildings was studied under 20 ground motions recorded in several developing nations all around the world. The peak ground acceleration (PGA) of the selected records ranges from $0.01 g$ to $1.78 g$. The moment magnitude and epicentral distance of the earthquakes associated with those ground motions range from 5.2 to 7.9 and 2.2 to $190 \mathrm{~km}$, respectively. The variation of PGA with moment magnitude and epicentral distance of the ground motions is shown in Figure 5.

In order to model uncertainties associated both with the ground motions and material properties, Latin hypercube sampling (LHS) technique is used in the present study to select the random variables. Using this technique, 20 sets of random parameters were selected and randomly combined with 20 ground motion records. Then, direct integration nonlinear timehistory analysis (NLTHA) of FB- and BI-URM buildings was carried out and the structural 
response is obtained. Thus, a total of 120 NLTHAs were carried out over the different cases considered in the study.

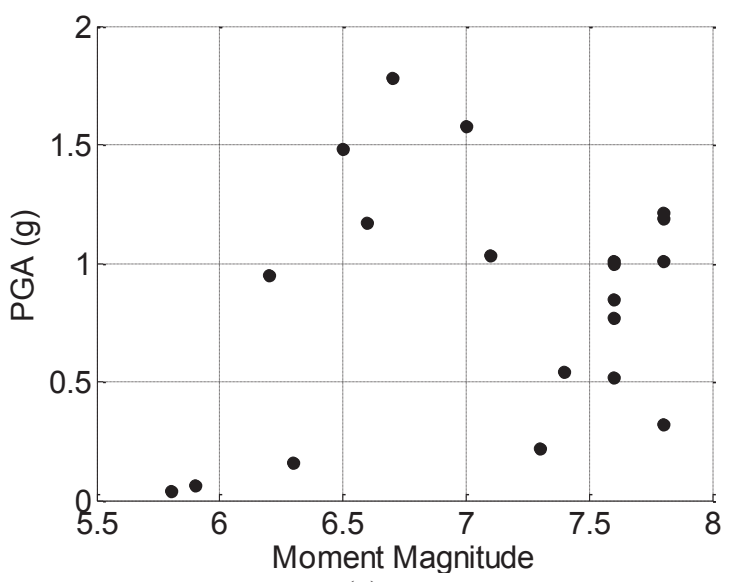

(a)

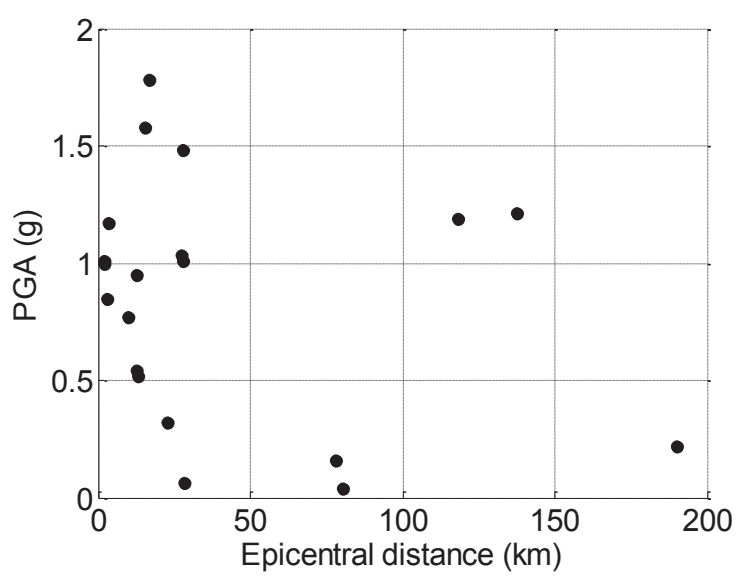

(b)

Figure 5: Selected input ground motion records: (a) PGA vs. moment magnitude; (b) PGA vs. epicentral distance.

\section{RESULTS AND DISCUSSION}

Structural response in terms of inter-storey drift ratio (IDR), which is the ratio between relative lateral displacement measured at the roof level and inter-story height, was computed for all case studies. IDR values were studied due to their direct correlation with the damage of the masonry buildings. The range of IDR corresponding to different damage levels varies in accordance with the building type and material strengths [31]. Previous studies suggest that IDR values greater than $0.2 \%$ usually correspond to extensive damage and significant strengthening interventions would be necessary. As far as isolators' displacements are concerned, a maximum response value was not explicitly given since the present study mainly focused on effectiveness of base isolation on seismic response of URM buildings. As a further development of the subject, the authors will study the fragility of the different structural components including base isolators.

\subsection{URM1 building}

The comparison between FB and BI configurations of URM1 building is shown in Figure 6. The results clearly highlight the effectiveness of base isolation. Under PGA $=1.78 g$, the reduction in IDR in the BI-URM building reaches approximately $91 \%$ whereas the reduction corresponding to the lowest PGA level, i.e. $0.04 g$, is about $40 \%$. It is also important to note that the IDR values of BI-URM1 building under all the earthquake excitations would be less than $0.2 \%$, which demonstrates the absence of extensive damage. Furthermore, comparatively higher reduction in IDR is observed under seismic excitations with PGA $>1 g$. The percentage reduction of IDR in BI-URM1 in comparison with FB-URM1 building is shown in Figure 7, with average value equal to $63 \%$ over all shaking intensities. For ground motion records with $\mathrm{PGA} \approx 1 g$, a wide variation in the building response is observed due to the combined variation in material properties and record characteristics. It can be noted that a linear regression model would be poorly accurate in providing an estimate of IDR reduction versus PGA due to significant non-linear behaviour in both FB- and BI-URM buildings. 


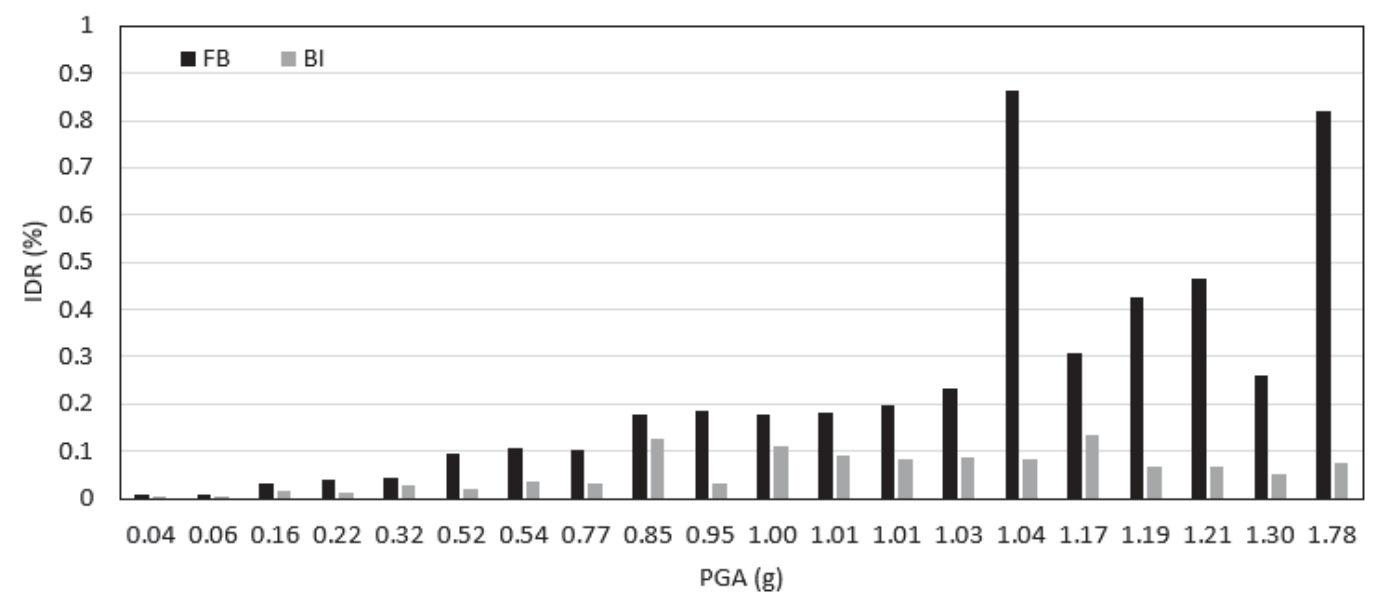

Figure 6: Seismic response of URM1 building.

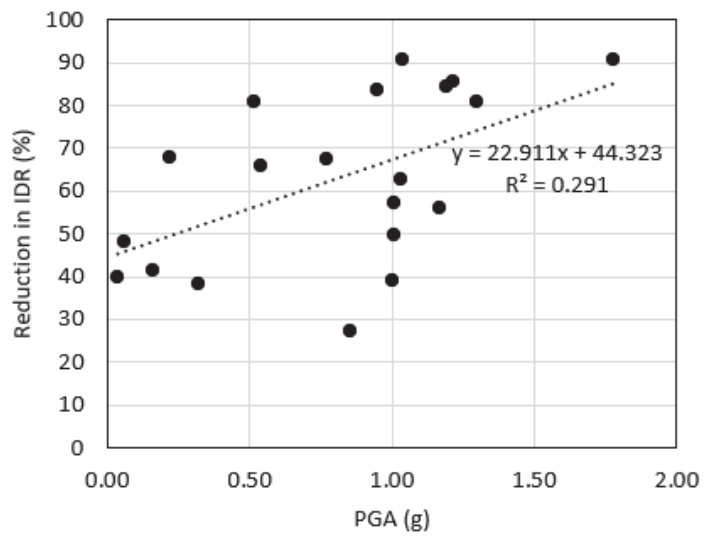

Figure 7: Percentage reduction in IDR of base isolated URM1 building.

\subsection{URM2 building}

URM2 building prototype is considered to identify the effect of base isolation with the variation in wall density along the direction of excitation (X-axis) and plan area in comparison with URM1 building. The response of URM2 building under earthquake excitations is shown in Figure 8. A significant reduction in IDR is observed in BI-URM2 building.

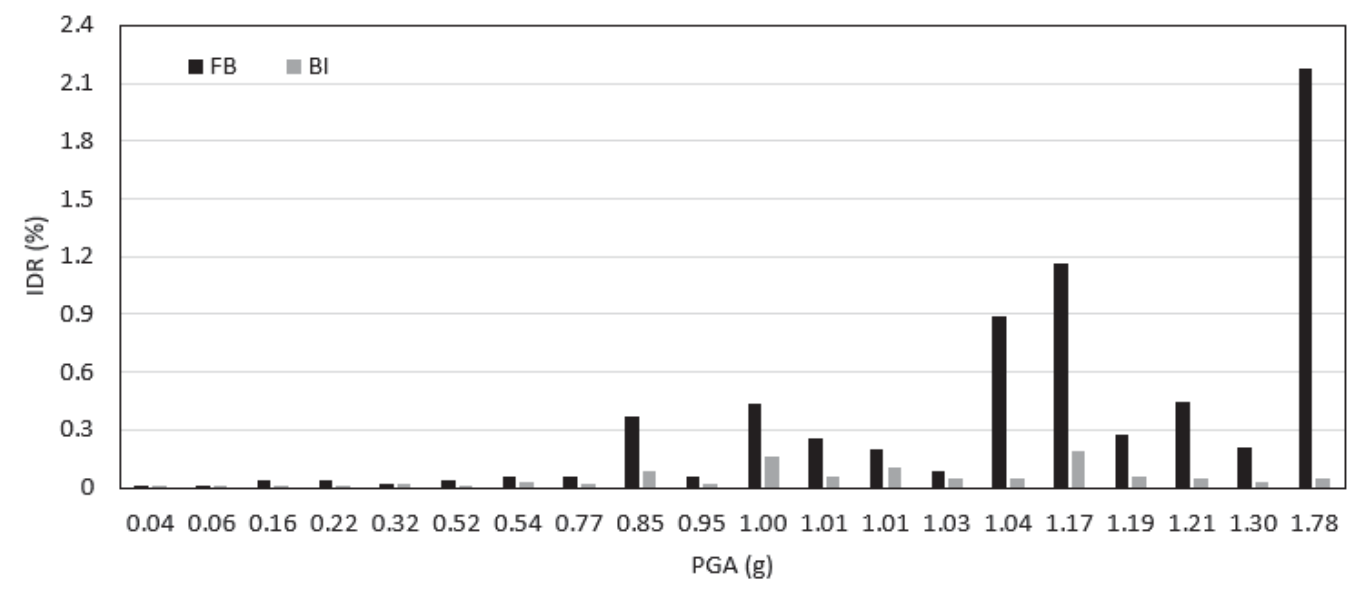

Figure 8: Seismic response of URM2 building. 
Similar to URM1 building, the base isolation technique is found to be more effective under seismic excitations with PGA $>1 g$. The reduction in IDR due to base isolation under earthquake ground motion with $\mathrm{PGA}=1.78 \mathrm{~g}$ is around $98 \%$ and response reduction in BI-URM2 building under varying PGA is shown in Figure 9. The average percentage reduction in IDR is about $66 \%$, i.e. a higher value in comparison with URM1 building.

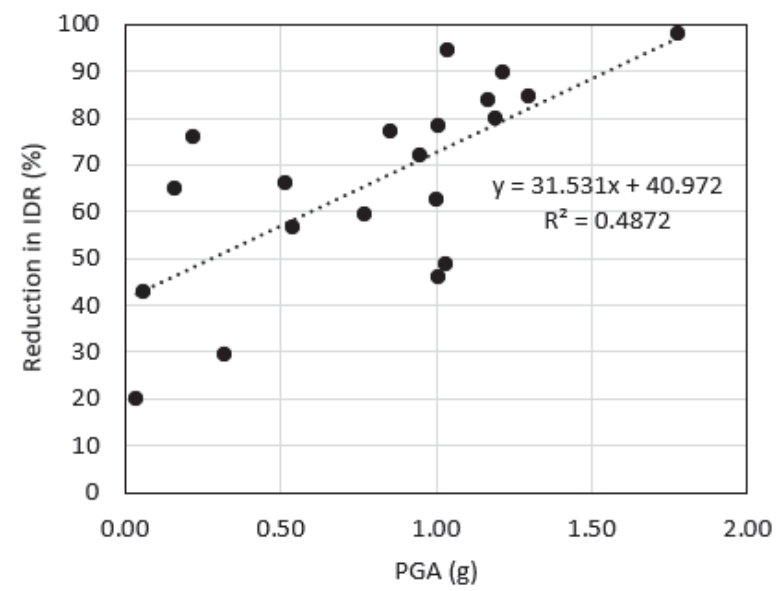

Figure 9: Percentage reduction in IDR of base isolated URM2 building.

\subsection{URM3 building}

URM3 building is considered in the present study to assess the effect of an increased number of storeys. The two-storey URM building is deemed more representative of a common building type found in developing nations, classified under low-to-medium income socioeconomic people. The building response in terms of IDR is shown in Figure 10 and the percentage reduction is given in Figure 11. The properly designed base isolation system offers a great reduction in terms of structural response, thus avoiding severe damage even under higher PGA levels. The average percentage reduction in IDR of URM3 building is about $81 \%$, which is significantly higher than that predicted on others URM buildings due to increased mass of the building. Differently from previous cases, a linear regression model would result more accurate in predicting IDR reduction. These outcomes confirm the effectiveness of RRFREIs under medium-size URM buildings, laying the basis for a further development of the subject.

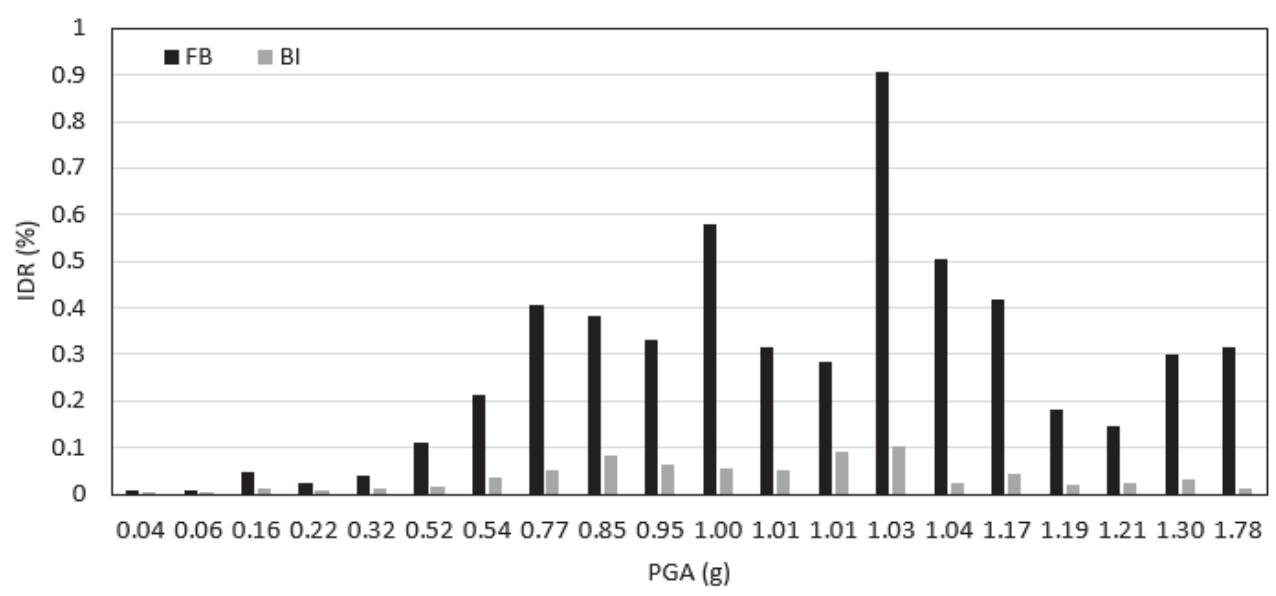

Figure 10: Seismic response of URM3 building. 


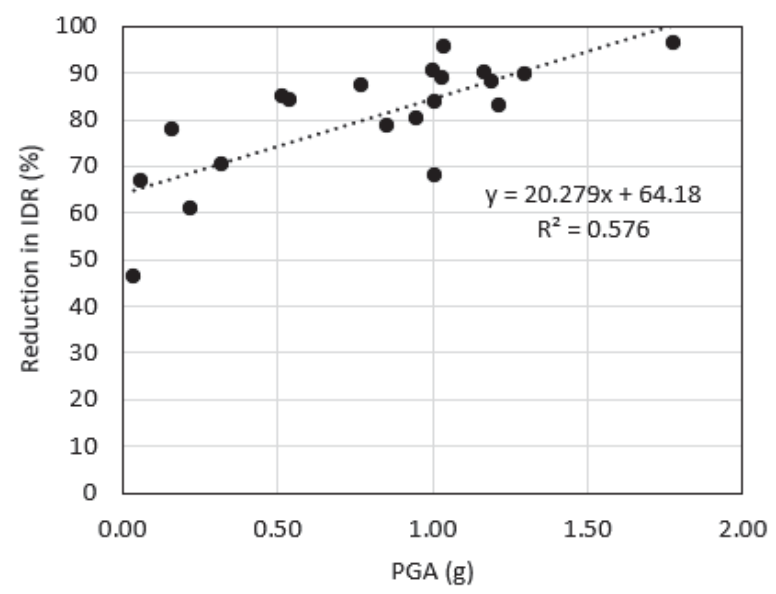

Figure 11: Percentage reduction in IDR of base isolated URM3 building.

\section{CONCLUSIONS}

In the present study, a low-cost base isolation system using recycled-rubber fibrereinforced bearings for URM buildings in developing countries is assessed. Three URM buildings are selected as representative of nonengineered constructions and the numerical models are developed in SAP2000 using nonlinear layered shell elements. The base isolation system is designed for all the selected buildings and modelled using a simplified bilinear model. Statistical distributions of material properties were calibrated from previous studies available in the literature. Then, the nonlinear time history analyses of the URM buildings were carried out under both fixed-base and base-isolated configurations. In order to consider the variability associated with both material properties and earthquake excitation, 20 sets of random variables were obtained through Latin hypercube sampling technique and each combined with a different earthquake ground motion recorded in developing countries. The results show a significant reduction in the IDR of the base-isolated URM buildings in comparison with their fixed-base counterparts under all selected ground motions. Furthermore, the reduction in IDR due to base isolation is more effective in URM2 and URM3 buildings in comparison with URM1 building due to their higher mass, i.e. a longer base isolation period is achieved due to a more stable geometry of the isolators. These promising results confirm the suitability of a novel low-cost base isolation concept for URM buildings in developing nations. The lower IDRs of the BI configuration are a major proxy of a significant reduction in the conditional probability of damage to the URM structure under seismic events. In next studies, the authors will thus investigate the seismic fragility of base isolated URM buildings, explicitly accounting for the limited displacement capacity of base isolators as additional critical parameter.

\section{REFERENCES}

[1] M. Valente, G.Milani, Non-linear dynamic and static analyses on eight historical masonry towers in the North-East of Italy. Engineering Structures, 114, 241-270, 2016.

[2] A.S. Arya, T. Boen, Y.Ishiyama, Guidelines for earthquake resistant non-engineered construction. UNESCO, 2014. 
[3] A. Naseer, A.N. Khan, Z. Hussain, Q. Ali, Observed seismic behavior of buildings in northern Pakistan during the 2005 Kashmir earthquake. Earthquake Spectra, 26(2), 425449, 2010.

[4] F. Naeim, J.M. Kelly, Design of seismic isolated structures: from theory to practice. John Wiley \& Sons, 1999.

[5] N. Vaiana, S. Sessa, F. Marmo, L. Rosati, An accurate and computationally efficient uniaxial phenomenological model for steel and fiber reinforced elastomeric bearings. Composite Structures, 211, 196-212, 2019.

[6] I.E.M. Sierra, D. Losanno, S. Strano, J. Marulanda, P. Thomson, Development and experimental behavior of HDR seismic isolators for low-rise residential buildings. Engineering Structures, 183, 894-906, 2019.

[7] J.M. Kelly, Analysis of fiber-reinforced elastomeric isolators. Journal of Seismology and Earthquake Engineering, 2(1), 19-34, 1999.

[8] N.C. Van Engelen, Fiber-reinforced elastomeric isolators: A review. Soil Dynamics and Earthquake Engineering, 125, 105621, 2019.

[9] M. Spizzuoco, A. Calabrese, G. Serino, Innovative low-cost recycled rubber-fiber reinforced isolator: experimental tests and finite element analyses. Engineering Structures, 76, 99-111, 2014.

[10] A. Calabrese, M. Spizzuoco, G. Serino, G. Della Corte, G. Maddaloni, Shaking table investigation of a novel, low-cost, base isolation technology using recycled rubber. Structural Control and Health Monitoring, 22(1), 107-122, 2015.

[11] D. Losanno, M. Spizzuoco, A. Calabrese, Bidirectional shaking-table tests of unbonded recycled-rubber fiber-reinforced bearings (RR-FRBs). Structural Control and Health Monitoring, 26(9), e2386, 2019.

[12] D. Losanno, A. Calabrese, I.E. Madera-Sierra, M. Spizzuoco, J. Marulanda, P. Thomson, G.Serino, Recycled versus natural-rubber fiber-reinforced bearings for base isolation: review of the experimental findings. Journal of Earthquake Engineering, 1-20, 2020.

[13] A. Calabrese, D. Losanno, M. Spizzuoco, S. Strano, M. Terzo, Recycled Rubber Fiber Reinforced Bearings (RR-FRBs) as base isolators for residential buildings in developing countries: The demonstration building of Pasir Badak, Indonesia. Engineering Structures, 192, 126-144, 2019.

[14] D. Losanno, N. Ravichandran, F. Parisi, A. Calabrese, G. Serino, Seismic performance of a Low-Cost base isolation system for unreinforced brick Masonry buildings in developing countries. Soil Dynamics and Earthquake Engineering, 141, 106501, 2021.

[15] Computers \& Structures, Inc, (CSI), SAP2000-Integrated software for structural analysis and design, Comput Struct, 2020.

[16] V.N. Thuyet, S.K. Deb, A. Dutta, Mitigation of seismic vulnerability of prototype lowrise masonry building using U-FREIs. Journal of Performance of Constructed Facilities, 32(2), 04017136, 2018.

[17] A.B. Habieb, M. Valente, G. Milani, Base seismic isolation of a historical masonry church using fiber reinforced elastomeric isolators. Soil Dynamics and Earthquake Engineering, 120, 127-145, 2019. 
[18] N. Ravichandran, A comparative study of phenomenological hysteretic models with application to recycled rubber-fibre reinforced bearings. Journal of Vibroengineering, 22(8), 1798-1813, 2020.

[19] N. Vaiana, M. Spizzuoco, G. Serino, Wire rope isolators for seismically base-isolated lightweight structures: experimental characterization and mathematical modeling. Engineering Structures, 140, 498-514, 2017.

[20] N. Vaiana, S. Sessa, M. Paradiso, L. Rosati, Accurate and efficient modeling of the hysteretic behavior of sliding bearings. In 7th International Conference on Computational Methods in Structural Dynamics and Earthquake Engineering (COMPDYN 2019), Crete, Greece, 2019.

[21] K. Shahzada, A.N. Khan, A.S. Elnashai, M. Ashraf, M. Javed, A. Naseer, B. Alam, Experimental seismic performance evaluation of unreinforced brick masonry buildings. Earthquake Spectra, 28(3), 1269-1290, 2012.

[22] T. Choudhury, G. Milani, H.B. Kaushik, Comprehensive numerical approaches for the design and safety assessment of masonry buildings retrofitted with steel bands in developing countries: The case of India. Construction and Building Materials, 85, 227-246, 2015 .

[23] Bureau of Indian Standards (IS:1893-Part 1), Criteria for earthquake resistant design of structures, 2002.

[24] S.B. Kadam, Y. Singh, L. Bing, Seismic fragility reduction of an unreinforced masonry school building through retrofit using ferrocement overlay. Earthquake Engineering and Engineering Vibration, 19, 397-412, 2020.

[25] A. Bakshi, K. Karimi, Performance evaluation of masonry buildings using a probabilistic approach, Scientia Iranica, 15(3), 295-307, 2013.

[26] Y. Singh, D.H. Lang, J.S.R. Prasad, R. Deoliya, An analytical study on the seismic vulnerability of masonry buildings in India. Journal of Earthquake Engineering, 17(3), 399422, 2013.

[27] N. Giordano, F. De Luca, A. Sextos, Analytical fragility curves for masonry school building portfolios in Nepal. Bulletin of Earthquake Engineering, 19(2), 1121-1150, 2021.

[28] H.B. Kaushik, D.C. Rai, S.K. Jain, Uniaxial compressive stress-strain model for clay brick masonry. Current Science, 497-501, 2007.

[29] A.H. Akhaveissy, G. Milani, Pushover analysis of large scale unreinforced masonry structures by means of a fully 2D non-linear model. Construction and Building Materials, 41, 276-295, 2013.

[30] N. Ravichandran, D. Losanno, F. Parisi, Comparative assessment of finite element macro-modelling approaches for seismic analysis of non-engineered masonry constructions. Bulletin of Earthquake engineering, Under review.

[31] G.M. Calvi, A displacement-based approach for vulnerability evaluation of classes of buildings. Journal of earthquake Engineering, 3(03), 411-438, 1999. 